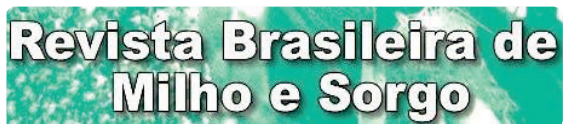

Brazilian Journal of Maize and Sorghum

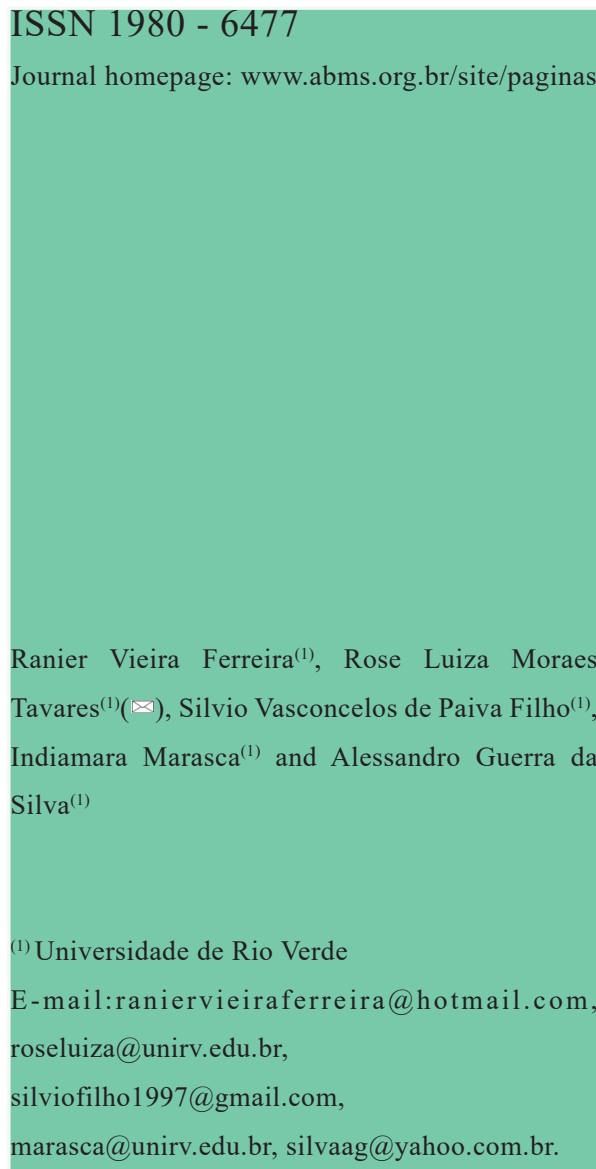

$\varangle$ Corresponding author

How to cite

FERREIRA, R. V.; TAVARES, R. L. M.; PAIVA FILHO, S. V.; MARASCA, I.; SILVA, A. G. Offseason strategies to improve soil physical attributes in no-till system in the brazilian cerrado. Revista Brasileira de Milho e Sorgo, v. 19, e1183, 2020.

\section{OFF-SEASON STRATEGIES TO IMPROVE SOIL PHYSICAL ATTRIBUTES IN NO-TILL SYSTEM IN THE BRAZILIAN CERRADO}

\begin{abstract}
In the central region of Brazil, Sorghum bicolor and Zea mays are considered viable crop alternatives to be cultivated during off-season periods, mainly to produce grains in succession to the cultivation of soybeans and in intercropping with Urochloa grasses. This study aimed to evaluate the physical qualities of the soil from an area with different off-season management histories (monoculture or agricultural intercropping). Z. mays, S. bicolor and Urochloa ruzizienses crops have been cultivated under no-tillage system. The experiment was conducted in a randomized complete block design, with four replications. The treatments included: 1) monoculture of $U$.ruzizienses; 2) monoculture of $S$. bicolor or Z. mays; and 3) intercropping of U. ruzizienses with S. bicolor or Z. mays. The following physical properties of the soil were evaluated: soil bulk density, porosity, soil resistance to penetration, soil moisture and texture, and organic carbon content, which were analyzed at 0-20, 20-40 and 40-60 cm soil depths. In the off-season, the cultivation of single $U$. ruzizienses promoted a greater amount of dry matter when compared with $S$. bicolor or $Z$. mays - U. ruzizienses intercropping. The topsoil presented better physical quality when compared with the adjacent layers in all evaluated systems. The use of $U$. ruzizienses combined with $S$. bicolor or $Z$. mays tends to improve the macro and micro porosity of the soil.
\end{abstract}

Keywords: Zea mays L, Sorghum bicolor, Urochloa ruzizienses, intercropping.

\section{ESTRATÉGIAS DE ENTRESSAFRA VISANDO A QUALIDADE FÍSICA DO SOLO EM SISTEMA DE PLANTIO DIRETO NO CERRADO BRASILEIRO}

\begin{abstract}
Resumo - Na região central do Brasil, Sorghum bicolor e Zea mays são alternativas viáveis como culturas de safrinha, principalmente, para a produção de grãos em sucessão ao cultivo da soja, e tem sido cultivadas de forma consorciada com gramíneas do tipo Urochloa. Este trabalho teve como objetivo avaliar a qualidade física do solo em área com diferentes históricos de manejo de entressafra (monocultivo ou consórcio agrícola) envolvendo as culturas Z. mays, S. bicolor e Urochloa ruzizienses em sistema de plantio direto. O ensaio foi conduzido com delineamento em blocos casualizados com quatro repetições, com os tratamentos: 1) monocultura de U. ruzizienses; 2) monocultura de S. bicolor ou Z. mays; e 3) consórcio de $U$. ruzizienses com S. bicolor ou Z. mays. Foram avaliadas propriedades físicas do solo como: densidade, porosidade, resistência do solo à penetração, umidade e textura do solo, além do teor de carbono orgânico nas profundidade $0-20 \mathrm{~cm}, 20-40 \mathrm{~cm}$ e $40-60 \mathrm{~cm}$. Na entressafra, o cultivo solteiro de $U$. ruzizienses promoveu maior quantidade de matéria seca quando comparado aos consórcios de S. bicolor-U. ruzizienses ou Z. mays - U. ruzizienses. A camada superficial do solo apresentou melhor qualidade física quando comparada com as camadas adjacentes em todos os sistemas avaliados. E o uso de $U$. ruzizienses consorciado com S. bicolor ou Z. mays tende a melhorar a macro e microporosidade do solo.
\end{abstract}

Palavras-chave: Zea mays L, Sorghum bicolor, Urochloa ruzizienses, consórcio. 
Z. mays has been grown in double-cropping system in Rio Verde, state of Goiás, Brazil, as a profitable alternative for the soybean off-season. The production partially meets the increasing demand of agro-industries in the region. However, the cultivation of single Z. mays has presented limitations to the production, which has led to the search for alternative crops in the off-season.

In this context, $S$. bicolor has also been considered promising for grain production (Silva et al., 2015), since it presents greater drought tolerance when compared to Z. mays (Silva et al., 2017). In order to meet the prerequisite for crop rotation in the no-tillage system, intercropping of $Z$. mays and S. bicolor with Urochloa can be considered viable alternatives (Horvathy Neto et al., 2014; Silva et al., 2014; Ribeiro et al., 2015). In general, intercropping does not affect grain yield and allows forage production in crop succession systems.

Grasses of the Urochloa genus present high adaptability, especially in the climate of the central region of Brazil (Ribeiro et al., 2015). Urochloa presents tolerance in soils with low fertility, good resistance to drought and cold, high growth rate, and ease of drying with glyphosate, which stimulates mass production, providing excellent soil coverage (Balbinot Junior et al., 2017).

Additionally, there are many benefits regarding the soil profile due to its aggressive root system capable of forming water infiltration channels in the soil (Rossi et al., 2012) and biopores for microbial activity and root breathing. According to Santos et al. (2008), the success of integrated agricultural systems in the Cerrado biome is due to the fact that the straw accumulated from forages provides a favorable environment for the recovery or maintenance of the soil properties.
Therefore, agricultural intercropping with Urochloa has been gaining space in the production systems, being able to supply plant residues in quantities suitable for the no-tillage system. According to Amado et al. (2001), under the conditions of the Cerrado biome, the annual addition of plant residues should not be less than 10 to $12 \mathrm{Mg} \mathrm{ha}^{-1}$ in order to maintain adequate amounts of soil organic matter.

Based on the above, this study aimed to evaluate the physical qualities of the soil from an area with different off-season management histories (monoculture or agricultural intercropping).

\section{Material and Methods}

\section{Experimental Area}

The experiment was conducted under field conditions at the University of Rio Verde $\left(17^{\circ} 46^{\prime} 58.65\right.$ "S and 50 58'13.08" W, altitude of $783 \mathrm{~m}$ ). The climate of the region is Aw, according to the Koppen classification, with the rain precipitation concentrated in the summer period (Figure 1). It presents two welldefined seasons (dry winter and humid summer). The soil was classified as a dystrophic Red Latosol (Oxisol) of clayey texture (Table 1).

\section{Treatments}

The treatments consisted of areas with different land-use histories in the off-season: Sorghum bicolor monoculture, Urochloa ruziziensis monoculture and S. bicolor - U. ruziziensis intercropping (identified as Strategy 1) and Zea mays monoculture, U. ruziziensis monoculture and Z. mays - U. ruziziensis intercropping (identified as Strategy 2). The two off-season strategies were spatially separated (independent experiments). 


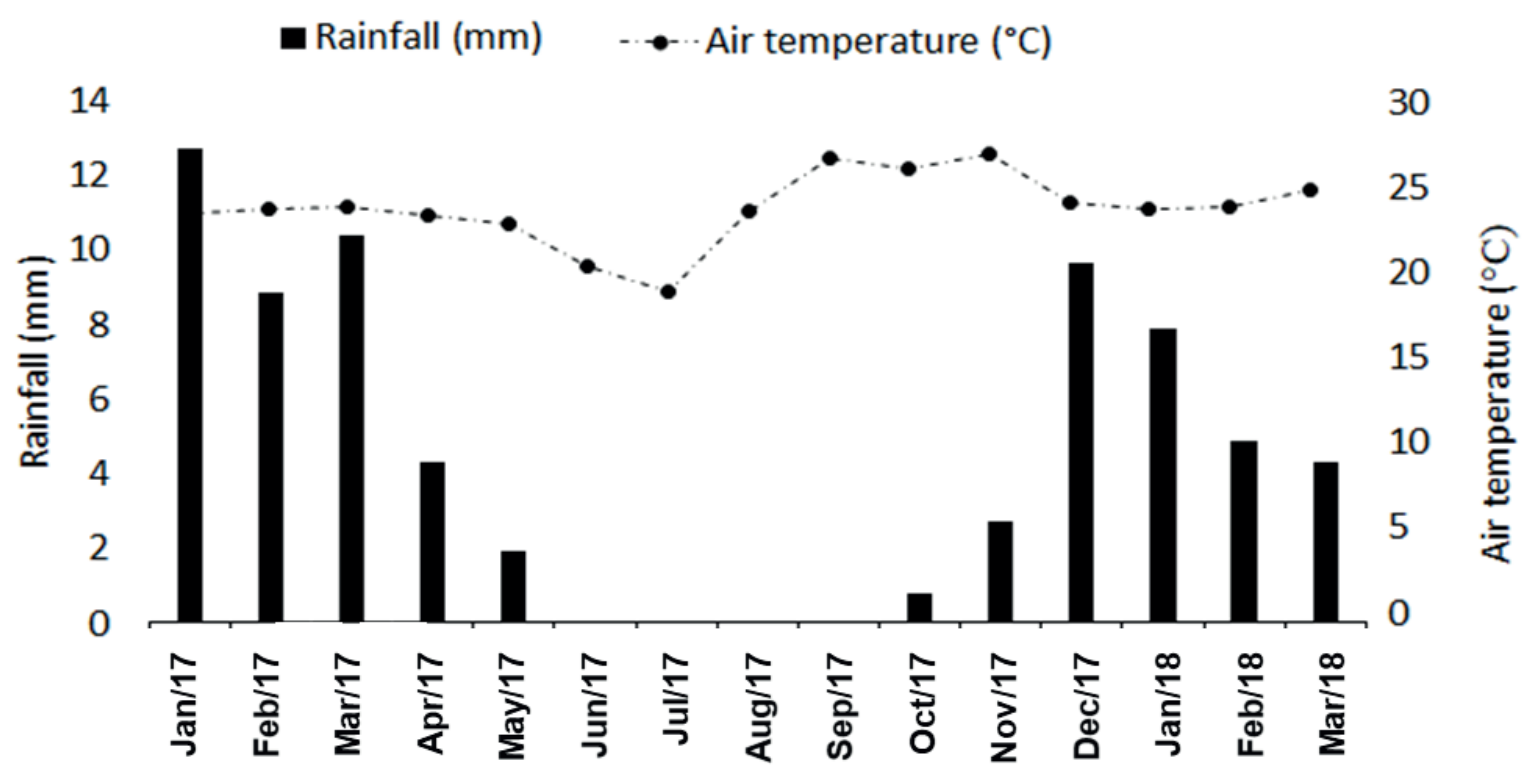

Figure 1. Monthly precipitation data (INMET, 2020) of the area cultivated under no-tillage systems, Rio Verde, state of Goiás, Brazil.

Table 1. Chemical characterization of the soil in an area under no-tillage system in Rio Verde, state of Goiás, Brazil.

\begin{tabular}{|c|c|c|c|c|c|c|c|c|c|c|c|c|c|}
\hline Depth & $\mathrm{P}$ & $\mathrm{S}$ & K & $\mathrm{Ca}$ & $\mathrm{Mg}$ & $\mathrm{Al}$ & CEC & $\mathrm{pH}$ & $\mathrm{V}$ & $\mathrm{OM}$ & Sand & Clay & Sil \\
\hline $\mathrm{cm}$ & \multicolumn{3}{|c|}{---- $\mathrm{mg} \mathrm{dm} \mathrm{dm}^{-3}$---- } & \multicolumn{4}{|c|}{----- $\mathrm{cmol}_{\mathrm{c}} \mathrm{dm}^{-3}$----- } & - & \multicolumn{5}{|c|}{-------------- $\%$--------------- } \\
\hline $0-20$ & 21.3 & 13.8 & 47.7 & 2.2 & 1.0 & 0.0 & 5.2 & 4.7 & 35.4 & 1.5 & 50 & 39 & 11 \\
\hline $20-40$ & 13.0 & 9.3 & 36.0 & 1.2 & 0.6 & 0.2 & 4.7 & 3.7 & 32.8 & 1.2 & 46 & 41 & 13 \\
\hline
\end{tabular}

The plots were organized in a randomized block design with four replications, totaling 12 plots for each management strategy. The plots consisted of eight lines with $45 \mathrm{~cm}$ spacing, being $9 \mathrm{~m}$ apart from each other.

In the first harvest season, soybean (maturation group 7.6 and variety “NA 7337 ” $\mathrm{RR}^{\circledR}$ ) was cultivated. The cultivar, with a population equivalent to 340,000 seeds ha-1 ${ }^{-1}$ was planted in October 2017 and harvested in January 2018. In the off-season, for the seeding of $S$. bicolor under monoculture or intercropping, the hybrid Taguá was used, with 170,000 seeds ha-1 planted in March 2017 and harvested in August 2017. As for Z. mays, the hybrid DKB 310 was used, with a population equivalent to 60,000 seeds $\mathrm{ha}^{-1}$ planted in February 2017 and harvested in July 2017. 
U. Ruziziensis seeds were sown together with the fertilizer application on the soil surface, at a bulk density equivalent to $13 \mathrm{~kg} \mathrm{ha}^{-1}, \mathrm{VC} 46 \%$. The amount of $170 \mathrm{~kg} \mathrm{ha}^{-1}$ of MAP (monoammonium phosphate) was used, with 200 and $150 \mathrm{~kg} \mathrm{ha}^{-1}$ of urea being surface-applied as first and second fertilization events, respectively. Before sowing, $150 \mathrm{~kg} \mathrm{ha}^{-1}$ of potassium chloride were distributed.

\section{Soil Sampling}

Undisturbed soil samples were collected for analysis of soil bulk density and porosity, while deformed samples were collected for analysis of soil organic carbon content, as well as moisture and texture.

To collect the undisturbed samples in each plot, a trench ( $0.4 \mathrm{~m}$ wide x $0.8 \mathrm{~m}$ long x $1.30 \mathrm{~m}$ deep) was opened, where undisturbed samples were removed in triplicates, using volumetric measurement of 100 $\mathrm{cm}^{3}$, at the depths of 0-20, 20-40 and 40-60.

The deformed samples were collected with the aid of a Dutch auger, at four different points, at the same depths mentioned above. Two samples were collected in the crop line and two samples were collected between the crop lines. The four individual samples were homogenized to form the composite sample, which was stored in plastic bag for further analysis.

\section{Soil Analysis}

The determination of the total organic carbon of the soil was carried out according to the methodology proposed by Sims \& Haby (1971), in which $1.0 \mathrm{~g}$ of air-dried fine earth was weighed in a 125 - mL Erlenmeyer flask, where $10 \mathrm{~mL}$ of 0.5 mol L-1 potassium dichromate solution $\left(\mathrm{K}_{2} \mathrm{Cr}_{2} \mathrm{O}_{7}\right)+$
$20 \mathrm{~mL}$ of concentrated sulfuric acid $\left(\mathrm{H}_{2} \mathrm{SO}_{4}\right)$ were added. After an incubation period of $20 \mathrm{~min}$ at room temperature, the sample volume was completed up to $100 \mathrm{~mL}$ with deionized water and the mixture was centrifuged at $6,800 \mathrm{rpm}$ for $10 \mathrm{~min}$. Subsequently, aliquots of $2 \mathrm{~mL}$ were collected, which were used for reading in a spectrophotometer with a wavelength of $600 \mathrm{~nm}$. A standard curve was made with a 7\% sucrose solution in different concentrations.

The analysis of soil bulk density was performed according to the methodology proposed by Embrapa (1997), which is based on the collection of soil samples with undisturbed structure by using a steel ring (Kopecky) with sharp edges and internal volume of $100 \mathrm{~cm}^{3}$. It is a simple analysis procedure that consists in obtaining the dry matter value of the soil after being subjected to a temperature of $105^{\circ} \mathrm{C}$ for 24 hours. The soil bulk density was calculated using the formula:

\section{Ds $\left(\mathrm{g} \mathrm{cm}^{-3}\right)=$ dry soilmass/ ring volume}

For determination of soil porosity, the undisturbed samples were saturated for 48 hours, followed by drainage at the potential equivalent to $0.006 \mathrm{MPa}$, using a tension table described by Kiehl (1979). From the moisture values, with sample saturation and water retention values, the values of macro, micro and total soil porosity were calculated, based on the following formulas, according to Embrapa (1997):

$$
\mathrm{P}_{\mathrm{T}}=\mathrm{V}_{\text {saturated sample }} / \mathrm{V}_{\text {ring }} \mathrm{Mi}=\mathrm{V}_{0.006} / \mathrm{V}_{\text {ring }} \mathrm{Ma}=\mathrm{P}_{\mathrm{T}}-\mathrm{Mi}
$$

in which, $\mathrm{P}_{\mathrm{T}}=$ total porosity; $\mathrm{V}_{\text {ring }}=$ volume of the 
volumetric ring; $\mathrm{Mi}=$ microporosity; $\mathrm{V}_{0.006}=$ volume of the sample subjected to a $0.006 \mathrm{MPa}$ tension; $\mathrm{Ma}=$ macroporosity.

The soil resistance to penetration was measured with an electronic penetrometer, in $\mathrm{MPa}$, by applying pressure using a conical rod into the soil up to $40 \mathrm{~cm}$ deep. Four different points within the plot were chosen, two in the line and two between the lines. The average value was considered.

\section{Dry Matter Content}

Contents of dry matter were calculated through the collection of green mass delimited by a $1 \mathrm{~m}^{2}$ wooden square, which was thrown in each plot at random for three times. The green mass was dried at $60{ }^{\circ} \mathrm{C}$ in a forced air circulation oven for $72 \mathrm{~h}$. The weight was extrapolated to $\mathrm{Mg} \mathrm{ha}^{-1}$.

\section{Statistical Analysis}

The experiment was carried out in a randomized block design, with four blocks subdivided into plots, with cultivation systems as the first factor (A) and collection depths as the second factor (B). Four replications were used, totaling 36 experimental units for each management strategy. Analysis of variance was performed and the Tukey test was applied at 5\% probability for comparison of means, using Sisvar statistical software (Ferreira, 2019).

\section{Results and Discussion}

The analysis of variance showed that there was a significant interaction effect between factors $\mathrm{A}$ (cultivation system) and B (soil depth), regarding total, macro and micro porosity, in the area cultivated with S. bicolor and U. ruziziensis. As for Z. mays, factors $\mathrm{A}$ and $\mathrm{B}$ presented a significant interaction effect for macroporosity (Table 2).

\section{Dry Matter and Soil Moisture}

The area with monoculture of $U$. ruziziensis showed the highest amount of dry matter $(\mathrm{p}<0.05)$, followed by the $S$. bicolor - U. ruziziensis intercropping and $S$. bicolor monoculture, with values of $14.47,10.48$ and $6.37 \mathrm{Mg} \mathrm{ha}^{-1}$, respectively (Figure 2-I). A similar trend was found for the second management strategy (Strategy 2), with values of $16.31,7.27$ and $6.65 \mathrm{Mg} \mathrm{ha}^{-1}$ for the area under $U$. ruziziensis monoculture, $Z$. mays monoculture and Z. mays - U. ruziziensis intercropping, respectively (Figure 2-II).

This result demonstrates the potential of Urochloa to promote soil mass aiming at soil quality in the Cerrado biome. According to Ribeiro et al. (2015), the Urochloa genus presents high adaptability, especially in the Cerrado soil, favoring the vegetal cover of the soil, crop rotation and its use as grazing in autumn-winter periods. Specifically, U. ruziziensis stands out for having adequate growth in soils with low fertility, good resistance to drought and cold, and high growth rate, which promotes great production of dry matter and excellent soil coverage (Balbinot Junior et al., 2017).

According to Amado et al. (2001), to maintain the soil organic matter content under the conditions found in the Cerrado, the annual addition of plant residues should not be less than 10 to 12 $\mathrm{Mg} \mathrm{ha}{ }^{-1}$. This indicates the importance of including Urochloa in the off-season, whether in monoculture or intercropping, bringing numerous benefits to soil conservation and quality, according to the time of implantation.

Probably, the greater amount of dry matter on the area with monoculture of $U$. ruziziensis 
Table 2. Results of analysis of variance for soil attributes in an area under no-tillage system in Rio Verde, state of Goiás, Brazil.

\begin{tabular}{|c|c|c|c|c|c|c|c|c|}
\hline SV & $\mathrm{DF}$ & $\mathrm{DM}$ & $\mathrm{SM}$ & $\mathrm{OC}$ & $\mathrm{BD}$ & PR & $\mathrm{Ma}$ & $\mathrm{Mi}$ \\
\hline \multicolumn{9}{|c|}{ Strategy $1-S$. bicolor and U. ruziziensis } \\
\hline Block & 3 & ns & ns & ns & $\mathrm{ns}$ & $\mathrm{ns}$ & $\mathrm{ns}$ & ns \\
\hline Factor A & 2 & $*$ & $*$ & ns & $\mathrm{ns}$ & $\mathrm{ns}$ & ns & ns \\
\hline Error $_{1}$ & 6 & - & - & - & - & - & - & - \\
\hline Factor B & 2 & - & $\mathrm{ns}$ & $* *$ & $* *$ & $* *$ & ns & $*$ \\
\hline$A^{*} B$ & 4 & - & ns & ns & $\mathrm{ns}$ & $\mathrm{ns}$ & $* *$ & $*$ \\
\hline Error $_{2}$ & 45 & - & - & - & - & - & - & - \\
\hline $\mathrm{CV}_{1}$ & - & 11.1 & 28.2 & 13.6 & 2.0 & 7.9 & 9.1 & 8.7 \\
\hline $\mathrm{CV}_{2}$ & - & 25.8 & 22.4 & 11.4 & 2.3 & 9.5 & 6.7 & 7.0 \\
\hline \multicolumn{9}{|c|}{ Strategy 2-Z. mays and U. ruziziensis } \\
\hline Block & 3 & ns & $\mathrm{ns}$ & $\mathrm{ns}$ & $\mathrm{ns}$ & ns & $\mathrm{ns}$ & ns \\
\hline Factor A & 2 & $*$ & ns & ns & $\mathrm{ns}$ & $\mathrm{ns}$ & $\mathrm{ns}$ & ns \\
\hline Error $_{1}$ & 6 & - & - & - & - & - & - & - \\
\hline Factor B & 2 & - & ns & $* *$ & $* *$ & $* *$ & $* *$ & ns \\
\hline$A * B$ & 4 & - & ns & ns & $\mathrm{ns}$ & $\mathrm{ns}$ & $*$ & ns \\
\hline Error $_{2}$ & 45 & - & - & - & - & - & - & - \\
\hline $\mathrm{CV}_{1}$ & - & 26.8 & 27.2 & 5.3 & 6.6 & 5.9 & 5.2 & 9.3 \\
\hline $\mathrm{CV}_{2}$ & - & 43.9 & 25.29 & 11.5 & 5.9 & 8.6 & 5.9 & 13.7 \\
\hline
\end{tabular}

DM: dry mass; SM: soil moisture; OC: organic carbon; BD: bulk density; PR: penetration resistance; Ma: macroporosity; Mi: microporosity; ${ }^{\text {ns }}$ not significant; * significant at $5 \%$ probability level; and ${ }^{* *}$ significant at $1 \%$ probability level.

promoted greater soil moisture. However, this effect was significant $(\mathrm{p}<0.05)$ in the management strategy with $S$. bicolor and/or U. ruziziensis (Figure 2- III), while in the area planted with Z. mays and/ or $U$. ruziziensis, the soil moisture presented similar results, regardless of the system (monoculture or intercropping) (Figure 2-IV). Rossi et al. (2013) also found higher soil moisture in intercropping systems and explained that soil moisture was favored due to the greater amount of dry matter.

\section{Organic Carbon}

The single or intercropped management systems for $U$. ruziziensis, S. bicolor and Z. mays did not present significant differences $(\mathrm{p}>0.05)$ regarding the organic carbon content of the soil (Table 2). Possibly, the difference can be observed in the second crop year. However, comparing the soil layers studied, the organic carbon was always higher $(p<0.05)$ in the topsoil $(0-20 \mathrm{~cm})$ when compared with depths of 20-40 and 40-60 cm, with values of 19.53, 14.75 and $13.31 \mathrm{mg} \mathrm{kg}^{-1}$, respectively, in the management system with $S$. bicolor and U. ruziziensis (Figure 3-I), 

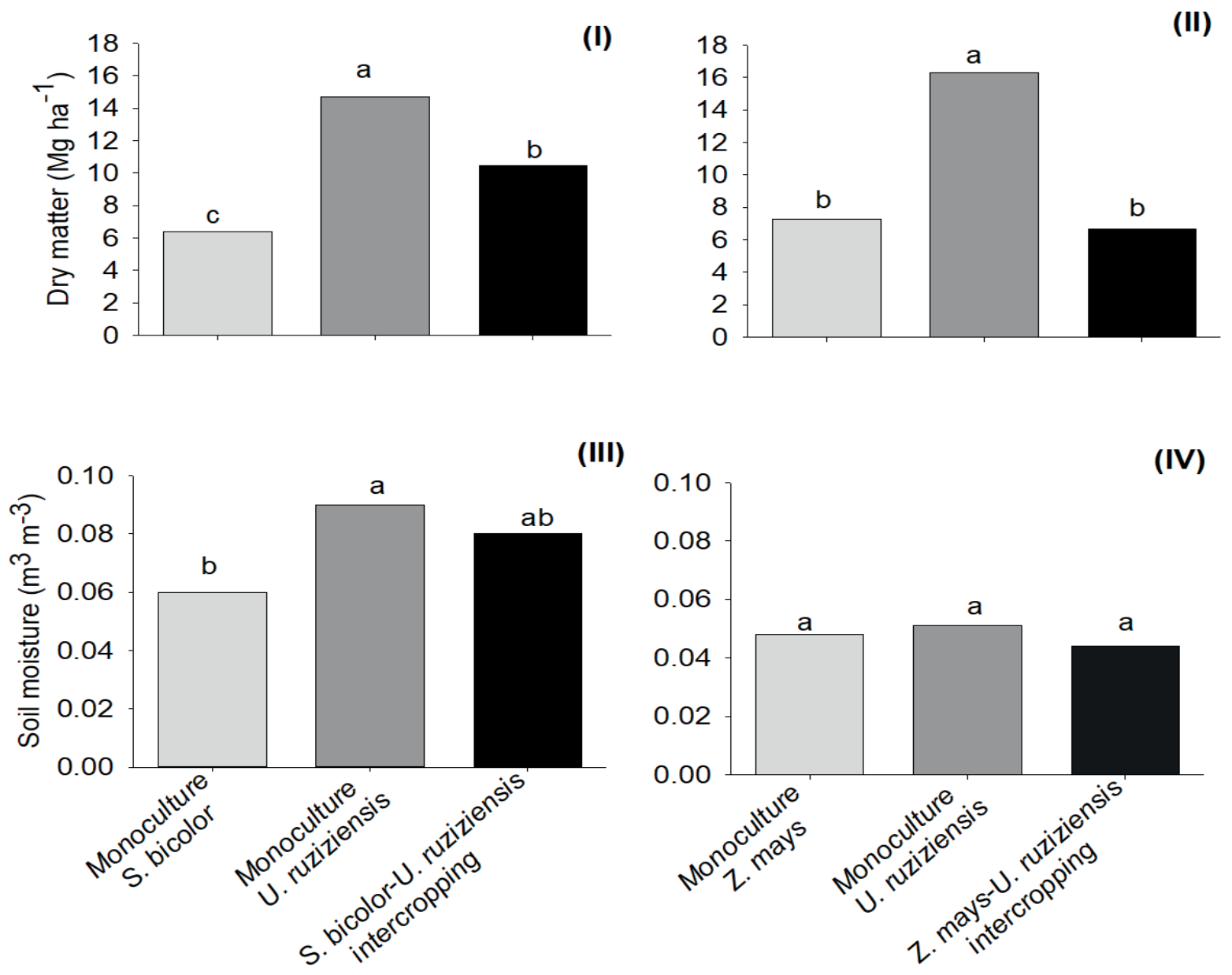

Figure 2. Effect of the use of single and intercropped crops, during the off-season, on the amount of dry matter (I, II) and soil moisture (III, IV) in an area under no-tillage system in Rio Verde, state of Goiás, Brazil.

and $13.19,11.32$ and $10.92 \mathrm{mg} \mathrm{kg}^{-1}$ in the $Z$. mays and U. ruziziensis management system (Figure 3-II). The carbon content in the soil decreases with the depth of the soil in a no-tillage system due to the residues being deposited on the surface (Tavares et al., 2019; Salton et al., 2012; Campos et al., 2011; Rossi et al., 2013; Rossi et al., 2012; Amado et al., 2001).

The forms of use and management of the soil are responsible for the entry of carbon into the system, as well as its exit from the soil into the atmosphere. In agricultural systems, this carbon input is influenced by soil preparation, species used, crop rotations, fertilization and, mainly, by crop residue management (Coser et al., 2016; Campos et al., 2011). The notillage system has shown success in the accumulation of organic matter, mainly in the superficial layer of the soil due to the greater proximity with the deposition of plant residues.

It is important to alert that the areas of this study showed an initial phase of no-tillage systems 


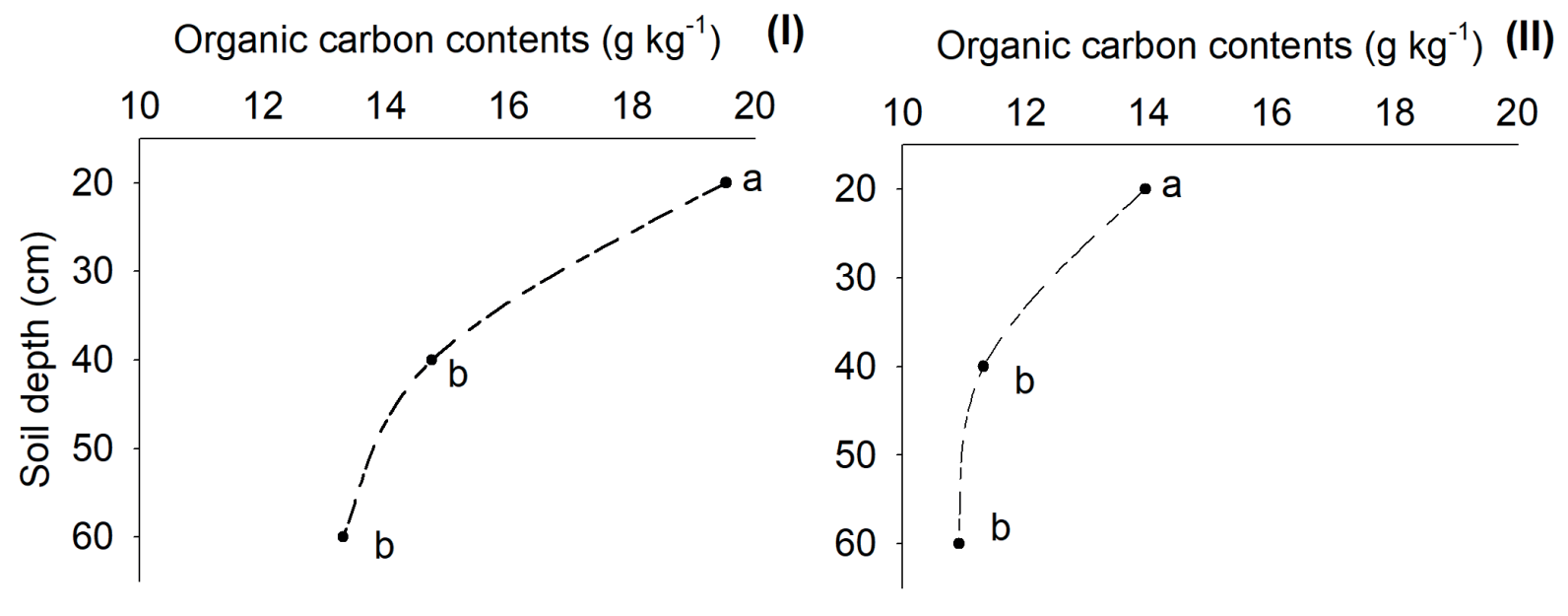

Figure 3. Organic carbon content of the soil at different depths, for management systems using S. bicolor and Urochloa (I) and Z. mays and U. ruziziensis (II), in an area under no-tillage system in Rio Verde, state of Goiás, Brazil.

and this can also explain why the carbon content is greater in the topsoil. In this sense, we believe that carbon can be increased in the soil depths with longer adoption of no-tillage system, due to the carbon protection by soil aggregation stability, and when including plant species such as $U$. ruziziensis with penetration potential in soil depth.

\section{Soil Bulk Density and Resistance to Penetration}

The best results of soil bulk density and resistance to penetration were observed in the topsoil (0-20 cm), regardless of the adopted management.

The area with management of sorghum and $U$. ruziziensis showed soil bulk density values of $1.63,1.68$ and $1.69 \mathrm{~kg} \mathrm{dm}^{-3}$ in the $0-20,20-40$ and 40-60 cm layers, respectively (Figure 4-I). As for the management of $Z$. mays and $U$. ruziziensis, the bulk density values were $1.55,1.47$ and $1.49 \mathrm{~kg} \mathrm{dm}^{-3}$ for the $0-20,20-40$ and $40-60 \mathrm{~cm}$ layers, respectively (Figure 4-II).

These values are considered critical for the type of soil in this study (clayey). According to a review study by Andrade \& Stone (2009), they should vary from 1.30 to $1.34 \mathrm{~kg} \mathrm{dm}^{-3}$ for root development without physical restrictions. The increase of soil bulk density in subsurface layers has been frequent in no-tillage systems as a result of minimum soil disturbance during planting (Tavares et al., 2019).

Soil resistance to penetration is a reflection of soil bulk density levels. Thus, it was possible to observe values, in the $20-40 \mathrm{~cm}$ layer, of 2.29 and $2.96 \mathrm{MPa}$, in the areas with management of $S$. bicolor and U. ruziziensis (Figure 4-III) and Z. mays and $S$. bicolor (Figure 4-IV), respectively, confirming the trend of compaction in the layers below that which was revolved in the no-tillage system. On a scale established by Arshad et al. (1996), the resistance to 


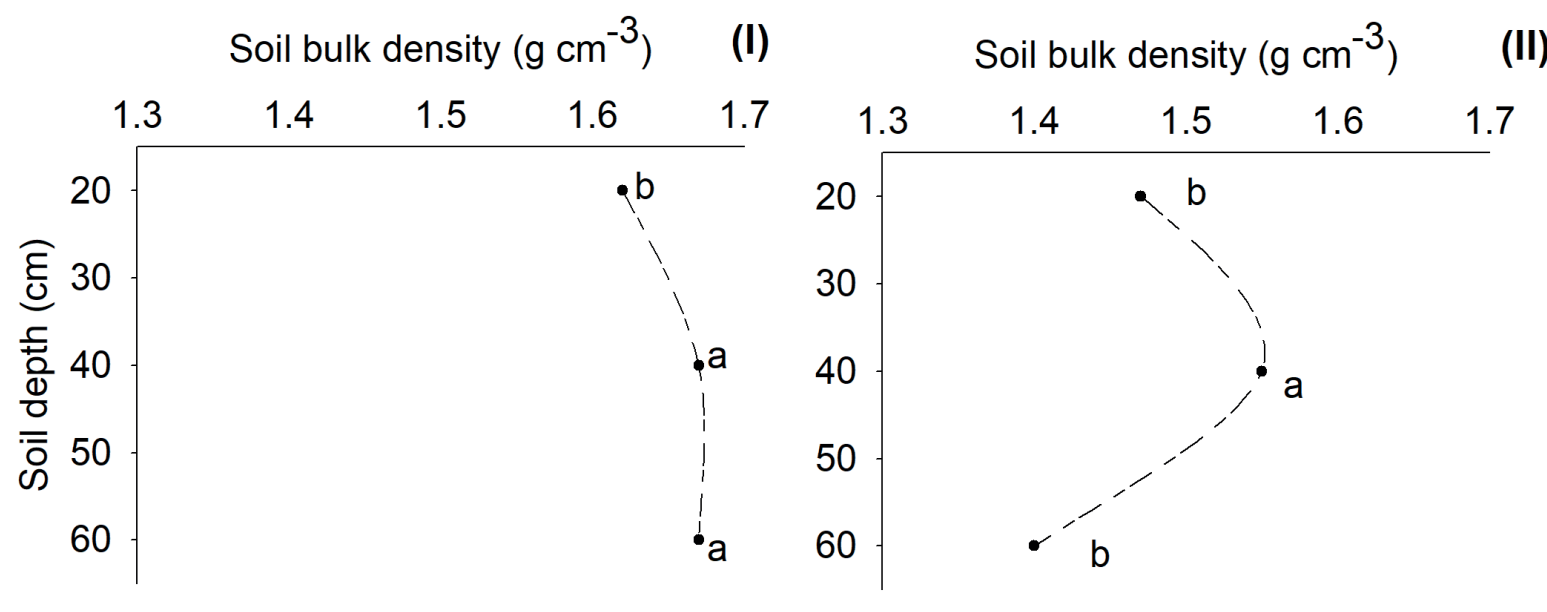

Soil resistance penetration $(\mathrm{MPa})(\mathrm{III})$

Soil resistance penetration (MPa) (IV)
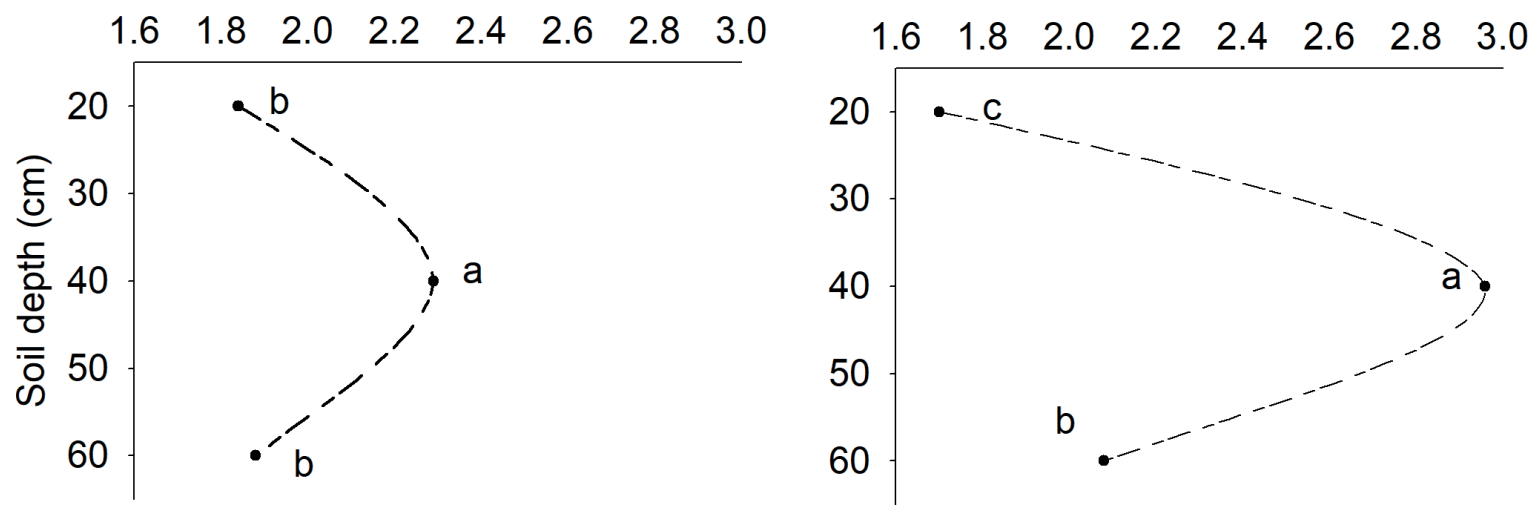

Figure 4. Soil bulk density (I, II) and soil penetration resistance (III, IV) in soil depths, in the off-season, in areas with single or intercropped sorghum and Urochloa (I, III) and Z. mays and U. ruziziensis (II, IV) crops, in Rio Verde, state of Goiás, Brazil.

penetration in the $20-40 \mathrm{~cm}$ layer can be considered high for clayey soils. However, it is important to note that the soil moisture was not ideal for evaluation (below the field capacity) (Tormena et al., 2017), which can cause confusion and characterize a false state of soil compaction. Because of this, it can be said that the soil presented compaction in the sub-superficial layer due to the evaluation of bulk density and not of resistance to penetration.

\section{Soil Macro and Microporosity}

Soil evaluations were carried out in an initial period of the no-tillage system, which may reflect the instability of the system. However, over time, the tendency of the system, mainly with the inclusion of $U$. ruziziensis in the off-season intercropping, is to improve the physical quality of the soil system, as confirmed in studies by Salton et al. (2012), Rossi et 
al. (2013), Horvathy Neto et al. (2014), and Balbinot Junior et al. (2017). Similarly, Seidel et al. (2015) also did not find improvements in the physical properties of the soil with the use of the Z. mays - U. ruziziensis intercropping.

The interaction between management systems and soil depths was significant for soil macro and micro porosity (Table 2), showing greater sensitivity to the other evaluated physical attributes. Likewise, Seidel et al. (2015), when evaluating physical attributes of the soil in a monoculture and intercropping system of Z. mays and U. ruziziensis, found that only the soil macroporosity showed differences with the management systems.

Therefore, it was possible to observe that, in the management system with $S$. bicolor and $U$. ruziziensis, the highest values of soil macroporosity were found in the areas with monoculture of $U$. ruziziensis and S. bicolor - U. ruziziensis intercropping, in the 20-40 cm layer (Table 3). This can be considered beneficial, since this layer showed strong bulk density and resistance to penetration. However, the macroporosity values above $0.10 \mathrm{~m}^{3} \mathrm{~m}^{-3}$ do not constitute restriction, according to Seidel et al. (2015) and Tormena et al. (1996), on the circulation of oxygen in the soil for root respiration.

For the management systems with Z. mays and $U$. ruziziensis, the soil macroporosity was also greater in the Z. mays - U. ruziziensis intercropping when compared with $Z$. mays monoculture in the $40-60 \mathrm{~cm}$, thus indicating that, in both management systems, the intercropping promoted greater soil macroporosity when compared with sorghum or $Z$. mays monoculture, whose potential can be attributed to the presence of $U$. ruziziensis and its potential for fasciculation of the roots in the soil.

In a study evaluating different cover plants, involving off-season Poaceae and Fabaceae, Mottin

Table 3. Average values of soil macro and micro porosity in an area under monoculture (sorghum, Urochloa and Z. mays) and agricultural intercropping (S. bicolor - U. ruziziensis and Z. mays - U. ruziziensis), in an area under no-tillage system in Rio Verde, state of Goiás, Brazil.

\begin{tabular}{|c|c|c|c|c|c|c|}
\hline \multirow{3}{*}{ Off-season cultivation system } & \multicolumn{3}{|c|}{ Macroporosity $\left(\mathrm{m}^{3} \mathrm{~m}^{-3}\right)$} & \multicolumn{3}{|c|}{ Microporosity $\left(\mathrm{m}^{3} \mathrm{~m}^{-3}\right)$} \\
\hline & \multicolumn{6}{|c|}{ Soil depth $(\mathrm{cm})$} \\
\hline & $0-20$ & $20-40$ & $40-60$ & $0-20$ & $20-40$ & $40-60$ \\
\hline & \multicolumn{6}{|c|}{ Strategy $1-S$. bicolor and U. ruziziensis } \\
\hline Monoculture S. bicolor & $0.18 \mathrm{aA}$ & $0.15 \mathrm{bB}$ & $0.17 \mathrm{aAB}$ & $0.20 \mathrm{aA}$ & $0.18 \mathrm{bB}$ & $0.19 \mathrm{aA}$ \\
\hline Monoculture U. ruziziensis & $0.16 \mathrm{aA}$ & $0.18 \mathrm{aA}$ & $0.18 \mathrm{aA}$ & $0.21 \mathrm{aA}$ & $0.21 \mathrm{aA}$ & $0.19 \mathrm{aA}$ \\
\hline \multirow[t]{2}{*}{ S. bicolor - U. ruziziensis intercropping } & $0.17 \mathrm{aA}$ & $0.17 \mathrm{aA}$ & $0.17 \mathrm{aA}$ & $0.19 \mathrm{aA}$ & $0.20 \mathrm{aA}$ & $0.19 \mathrm{aA}$ \\
\hline & \multicolumn{6}{|c|}{ Strategy 2 - Z. mays and U. ruziziensis } \\
\hline Monoculture Z. mays & $0.16 \mathrm{aA}$ & $0.14 \mathrm{aB}$ & $0.15 \mathrm{bB}$ & $0.18 \mathrm{aA}$ & $0.17 \mathrm{aA}$ & $0.19 \mathrm{aA}$ \\
\hline Monoculture $U$. ruziziensis & $0.16 \mathrm{aA}$ & $0.14 \mathrm{aB}$ & $0.15 \mathrm{bB}$ & $0.20 \mathrm{aA}$ & $0.18 \mathrm{aA}$ & $0.19 \mathrm{aA}$ \\
\hline Z. mays - U. ruziziensis intercropping & $0.15 \mathrm{aA}$ & $0.14 \mathrm{aB}$ & $0.17 \mathrm{aA}$ & $0.18 \mathrm{aA}$ & $0.18 \mathrm{aA}$ & $0.20 \mathrm{aA}$ \\
\hline
\end{tabular}

Means followed by the same letter (lower case in the column and upper case in the row) do not differ by the Tukey test at $5 \%$ probability. 
(2016) detected the potential for using U. ruziziensis to increase soil macroporosity and attributed this effect to the root structure of the plant. According to Kondo et al. (2012), a fasciculate root system tends to promote a greater volume of macropores in the soil due to the better aggregation promoted by the higher root density and release of exudates.

Soil microporosity showed the same tendency as soil macroporosity in the $20-40 \mathrm{~cm}$ layer for the management system with $S$. bicolor and $U$. ruziziensis, with higher values found in systems where $U$.ruziziensis was included. The $U$.ruziziensis had the potential to improve both soil macro and micro porosity, reflecting in better infiltration and water retention in the soil. Thus, the use of Urochloa in the no-tillage system is promising for proper structuring of the soil through the formation of stable aggregates (Kondo et al., 2012) and for increase in macroporosity, providing a favorable environment for the growth of the root system of the crop.

\section{Conclusions}

The monoculture or intercropping system involving $U$. ruziziensis with sorghum or $Z$. mays did not affect the organic carbon content, soil bulk density and resistance of the soil to penetration, in the first management cycle of these crops in the offseason.

The topsoil presented better physical qualities when compared with the adjacent layers under notillage system.

The use of $U$. ruziziensis combined with $S$. bicolor or Z.mays tends to improve the macro and micro porosity of the soil.

\section{Acknowledgment}

This work was supported by the University of Rio Verde and this study was financed in part by the Coordenação de Aperfeiçoamento de Pessoal de Nível Superior - Brasil (CAPES) - Finance Code 001.

\section{References}

AMADO, T.J.C.; BAYER, C.; ELTZ, F.L.F.; BRUM, A.C.R. Potencial de culturas de cobertura em acumular carbono e nitrogênio no solo no plantio direto e a melhoria da qualidade ambiental. Revista Brasileira de Ciência do Solo, v.25, n.1, p.189-197, 2001. DOI: 10.1590/S0100-06832001000100020.

ANDRADE, R. S.; STONE, L. F. Índice S como indicador da qualidade física de solos do cerrado brasileiro. Revista Brasileira de Engenharia Agrícola e Ambiental, v.13, n.4, p.382-388, 2009. DOI: $10.1590 / \mathrm{S} 1415-43662009000400003$.

ARSHAD, M. A.; LOWERY, L.; GROSSMAN, B. Physical tests for monitoring soil quality. In: DORAN, J. W; JONES, A. J. (Eds.) Methods for assessing soil quality. Madison: Soil Science Society of America, 1996. p.123-142. Special Publication, 49

BALBINOT JUNIOR, A.A.; FRANCHINI, J.C.; DEBIASI, H.; YOKOYAMA, A.H. Contribution of roots and shoots of Urochloa species to soybean performance in succession. Pesquisa Agropecuária Brasileira, v.58, p.592-598, 2017. DOI: 10.1590/ s0100-204x2017000800004.

CAMPOS, B.C.; AMADO, T.J.C.; BAYER, C.; NICOLOSO, R. S.; FIORIN, J.E. Carbon stock and its compartments in a subtropical oxisol under long-term 
tillage and crop rotation systems. Revista Brasileira de Ciência do Solo, v. 35, n. 3, p. 805-817, 2011. DOI: 10.1590/S0100-06832011000300016.

ClAESSEN, M. E. C. (Org.). Manual de métodos de análise de solo. 2. ed. rev. atual. Rio de Janeiro: Embrapa-CNPS, 1997. 212 p. (Embrapa-CNPS. Documentos, 1).

COSER, T.R.; RAMOS, M.L.G.; FIGUEIREDO, C.C.D.; CARVALHO, A.M.D.; CAVALCANTE, E.; MOREIRA, M.K.D.R.; ARAUJO, P.S.; OLIVEIRA, S.A.D. Soil microbiological properties and available nitrogen for corn in monoculture and intercropped with forage. Pesquisa Agropecuária Brasileira, v. 51, n.9, p. 1660-1667, 2016. DOI: 10.1590/s0100204x2016000900066.

FERREIRA, Daniel Furtado. SISVAR: A computer analysis system to fixed effects split plot type designs. Revista Brasileira de Biometria, v. 37, n. 4, p. 529535, dec. 2019. ISSN 1983-0823.

HORVATHY NETO, A.; SILVA, A. G da.; TEIXEIRA, I. R.; COSTA, K. A. de P.; ASSIS, R. L de. Consórcio de sorgo granífero e braquiária na safrinha para a produção de grãos e forragem. Revista Caatinga, v. 27, n. 3, p. 132-141, 2014.

INMET - Instituto Nacional de Meteorologia. Banco de dados meteorológicos para ensaio e pesquisa. Disponível: www.inmet.gov.br. Acesso em 15/01/2020.

KIEHL, E. J. Manual de edafologia. São Paulo: Agronômica Ceres, 1979. 262p.
WENDlinG, B.; SILVA, P. B.; CARDOSO, M. M. Efeito de coberturas vegetais sobre os atributos físicos do solo e características agronômicas do sorgo granífero. Bioscience Journal, v. 28, suplemento 1, p. 33-40, 2012.

MOTTIN, M. C. Efeito de plantas de cobertura cultivadas no inverno nas propriedades físicas do solo e na produtividade de soja e milho em sucessão. 2016. 65 f. Dissertação (Mestrado) - Universidade Estadual do Oeste do Paraná, Cascavel, PR, 2016.

RIBEIRO, M. G.; COSTA, K. A. P.; SILVA, A. G.; SEVERIANO, E. C.; SIMON, G. A.; CRUVINEL, W. S.; SILVA, V. R.; SILVA, J. T. Grain sorghum intercropping with Brachiaria brizantha cultivars in two sowing systems as a double crop. African Journal of Agricultural Research, v. 10, n. 39, p. 37593766, 2015. DOI: 10.5897/AJAR2015.9705.

ROSSI, C.Q.; PEREIRA, M.G.; GIÁCOMO, S.G.; BETTA, M.; POLIDORO, J.C. Decomposição e liberação de nutrientes da palhada de braquiária, sorgo e soja emáreas de plantio direto no cerrado goiano. Semina: Ciências Agrárias, v. 34, n. 4, p. 1523-1534, 2013. DOI: 10.5433/1679-0359.2013v3 $4 \mathrm{n} 4 \mathrm{p} 1523$.

ROSSI, C.Q.; PEREIRA, M.G.; GIÁCOMO, S.G.; BETTA, M.; POLIDORO, J.C. Frações lábeis da matéria orgânica em sistemas de cultivo com palha de braquiária e sorgo. Revista Ciência Agronômica, v. 43, n. 1, p. 38-46, 2012. DOI: 10.1590/S180666902012000100005 .

KONDO, M. K.; AlBUQUERQUE, C. J. B.; SALTON, J.C.; MIELNICZUK, J.; BAYER, C.; 
FABRÍCIO, A.C.; MACEDO, M.C.M.; BROCH, D.L. Teor e dinâmica do carbono no solo em sistemas de integração lavoura-pecuária. Pesquisa Agropecuária Brasileira, v. 46, n. 10, p. 1349-1356, 2012. DOI: 10.1590/S0100-204X2011001000031.

SANTOS, G. G.; SILVEIRA, P. M.; MARCHÃO, R. L.; BECQUER, T.; BALBINO, L. C. Macrofauna edáfica associada a plantas de cobertura em plantio direto em um latossolo vermelho do Cerrado. Pesquisa Agropecuária Brasileira, v.43, p.115-122, 2008. DOI: 10.1590/S0100-204X2008000100015.

SEIDEL, E. P.; MATTIA, V.; MATTEI, E.; CORBARI, F. Produção de matéria seca e propriedades físicas do solo na consorciação milho e braquiária. Scientia Agraria Paranaensis, v. 14, n. 1, p. 18-24, 2015. DOI: 10.18188/sap.v14i1.8226.

SILVA, A. G.; MORAES, L. E.; HORVATHY NETO, A.; TEIXEIRA, I. R.; SIMON, G. A. Consórcio sorgo e braquiária na entrelinha para produção de grãos, forragem e palhada na entressafra. Revista Ceres, v. 61 , n. 5, p. 697-705, 2014. DOI: 10.1590/0034$737 \mathrm{X} 201461050013$.

SILVA, A. G.; HORVATHY NETO, A.; TEIXEIRA, I. R.; COSTA, K. A. P.; BRACCINI, A. L. Seleção de cultivares de sorgo e braquiária em consórcio para produção de grãos e palhada. Semina: Ciências Agrárias, v. 36, n. 5, p. 2951-2964, 2015. DOI: 10.5433/1679-0359.2015v36n5p2951.
SILVA, A. G.; ANDRADE, C. L. L.; GOULART, M. M. P.; TEIXEIRA, I. R.; SIMON, G. A.; MOURA, I. C. S. Consórcio de sorgo granífero com braquiárias na safrinha para produção de grãos e biomassa. Revista Brasileira de Milho e Sorgo, v.16, p. 495-508, 2017. DOI: 10.18512/1980-6477/rbms.v16n3p495-508.

SIMS, J. R.; HABY, V. A. Simplified colorimetric determination of soil organic matter. Soil Science, v. 112, p. 137-141, 1971.

TAVARES, R. L. M.; ASSIS, R. L.; FERREIRA, R. V. F.; MENEZES, J. F. S.; SIMON, G. A.; BOLDRIN, P. F.; CANTÃO, V. C. G. Long term application of pig manure on the chemical and physical properties of Brazilian Cerrado soil. Carbon Managment, v. 10, p. 541-540, 2019. DOI: 10.1080/17583004.2019.1676095.

TORMENA, C. A.; ANGHINONI, E.; WATANABE, R.; FERREIRA, C. J. B. Qualidade física do solo em sistemas intensivos de produção agrícola. Boletim de Pesquisa. Fundação MT, p.109-124, 2017.

TORMENA, C. A.; ROLOFF, G. Dinâmica da resistência à penetração de um solo sob plantio direto. Revista Brasileira de Ciência do Solo, v.20, n.3, p.333-339, 1996. 